\title{
I nvolvement of fungal species in bovine mastitis in and around Mathura, India
}

\author{
Sarita Pachauri, Puneet Varshney, Sandeep Kumar Dash and Manoj Kumar Gupta
}

Department of Microbiology and Immunology

Pandit Deen Dayal Upadhyaya Veterinary and Animal Sciences University, Mathura, UP, India

Corresponding author: Sandeep Kumar Dash, email: sandeepkumar.dash@gmail.com

Received: 04-11-2012, Accepted: 13-12-2013, Published online: 12-04-2013

\section{How to cite this article:}

Pachauri S, Varshney P, Dash SK and Gupta MK (2013) Involvement of fungal species in bovine mastitis in and around Mathura, India, Vet World 6(7):393-395, doi: 10.5455/vetworld.2013.393-395

\begin{abstract}
Aim: To study the prevalence of mycotic mastitis in bovines of Mathura region.

Materials and Methods: A total of 100 milk samples collected from seven different regions of Mathura were examined by cultural, morphological and biochemical methods.

Results: Out of 100 milk samples processed 64 samples were found positive for fungal isolates. The most common isolates were Candida albicans, Aspergillus fumigatus and Aspergillus niger.

Conclusion: The results of the present study suggest that Candida spp and Aspergillus spp are the main fungi involved in bovine mastitis in this region. Good hygiene and sanitation practices of animal farm and judicious use of antibiotics will lower incidence of bovine mycotic mastitis.
\end{abstract}

Keywords: Aspergillus, bovine, candida, fungus, mastitis, Mathura

\section{Introduction}

Mastitis is the inflammation of the mammary gland. It is widespread in dairy herds and associated with a significant reduction in milk yield resulting in increased costs of production and deteriorated quality of milk and milk products [1]. Mastitis is characterized by partial or complete damage to udder tissues which is usually a consequence of microbial infection. A wide variety of microorganisms have been implicated as causative agent of bovine mastitis including bacteria and fungi [2].

Seriousness of mycotic infection of mammary glands depends upon the species of the fungus involved as well as the percentage of infectivity. Treatment of mycotic mastitis is a challenge as many of these fungi do not respond to the antibiotics therapy rather they use some of the antibiotics like tetracycline as their source of energy [3].

In routine mastitis therapy antibiotics are used more often and much emphasis is not given on the antifungal therapy. Due to this reason most of the mastitis cases not only become incurable but also act as a source of infection for other lactating animals in the herd. Therefore it has become necessary to know about the fungal spp. playing role in mastitis, which could be differentially diagnosed and pinpoint therapy should be given to the animals.

Though there are many reports of fungal involvement in bovine mastitis around the globe, still

This article is an open access article licensed under the terms of the Creative Commons Attribution License (http://creativecommons. org/licenses/by/2.0) which permits unrestricted use, distribution and reproduction in any medium, provided the work is properly cited. very little work is done in India. Present study was undertaken to know the prevalence of fungal infections and the species involved in clinical and sub-clinical mastitis.

\section{Materials and Methods}

A total of 100 milk samples were collected for fungal isolation from March to May 2010 (Table-1). Out of these 20 milk samples were collected from clinical mastitis cases and 80 milk samples were collected from apparently healthy cows and buffaloes. $15 \mathrm{ml}$ of milk was collected from each animal and transported to laboratory under ice. Milk samples were examined for colour, consistency and $\mathrm{pH}$. Samples were streaked on Saboraud's dextrose agar plates. The plates were incubated at $37^{\circ} \mathrm{C}$ and examined for growth at 24, 48 and 72 hours and at weekly intervals for 4 weeks after which the plates showing no growth were considered negative [3]. The colonies were picked up and re-streaked on another SDA plate to get the pure cultures. These fungal isolates were studied for their cultural and morphological characteristics. The morphological characteristics were noted after staining with Gram's and Lacto phenol cotton blue stain. Isolates were identified by different sugar fermentation test. Briefly, $1 \%$ solution of different sugar solutions were dispensed into separate tubes and fungal isolates were inoculated in these tubes. The tubes were then incubated at $37^{\circ} \mathrm{C}$ for $24-48$ hours. The results were indicated by the change of colour [4].

\section{Results}

Out of 100 samples, 64 samples (14 from clinical 
Table-1. Samples collected from different places

\begin{tabular}{llclr}
\hline Sr. No. & Milk Samples & Total & Areas & No. of samples \\
\hline 1. & Clinical Samples & 20 & Kothari Hospital Veterinary University, Mathura & 20 \\
2. & Subclinical samples & 80 & Haridayal Goshala,Vrindavan & 10 \\
& & Shriji baba Goshala,Mathura & 10 \\
& & Panchayanti Goshala, Raman Reti & 20 \\
& & DDD Farm-Mathura & 20 \\
& & Krishna farm-Mathura & 10 \\
& & & Daudayal farm-Baldeo Mathura & 10 \\
& & & & 100
\end{tabular}

Table-2. Species wise isolation from different samples

\begin{tabular}{|c|c|c|c|c|c|c|}
\hline Sr. No. & Type of sample & Total no of Sample & $\begin{array}{l}\text { No. positive for } \\
\text { fungus isolation }\end{array}$ & Species isolated & No. of isolates & $\begin{array}{l}\text { Percentage } \\
\text { infectivity }\end{array}$ \\
\hline 1 & Clinical & 20 & 14 & $\begin{array}{l}\text { Candida albicans } \\
\text { Asprgillus fumigatus } \\
\text { Aspergillus niger }\end{array}$ & $\begin{array}{l}6 \\
3 \\
5\end{array}$ & $\begin{array}{l}30 \\
15 \\
25\end{array}$ \\
\hline 2 & Subclinical & 80 & 50 & $\begin{array}{l}\text { Candida albicans } \\
\text { Asprgillus fumigatus } \\
\text { Aspergillus niger }\end{array}$ & $\begin{array}{l}20 \\
14 \\
16\end{array}$ & $\begin{array}{c}25 \\
17.5 \\
20\end{array}$ \\
\hline
\end{tabular}

cases and 50 from subclinical cases), were found positive for fungal isolation. Of the 64 isolates, 26 isolates yielded smooth white or yellowish, cottony colonies having resemblance with Candida spp. Upon microscopic examination these isolates showed ovalshaped budding cells. Sugar fermentation test revealed that the isolates can ferment glucose, maltose and trehalose but cannot ferment lactose and sucrose. These 26 isolates were tentatively identified as Candida albicans [5].

Remaining 38 isolates yielded rapidly growing colonies with green or black pigmentation, showing resemblance with Aspergillus spp. Out of 38 isolates 17 , revealed granular to cottony colony, septate mycelium with their conidiophores long and have clubshaped vesicles. Vesicles were uniseriate and only the distal half was covered by conidia. These 17 isolates were identified as Aspergillus fumigatus. Rest 21 of Aspergillus spp. revealed long non-septate conidiophore with black spore heads with rapidly growing colonies. Vesicle was obscured due to profuse conidiation. These 21 isolates were tentatively identified as Aspergillus niger (Table-2) [6].

\section{Discussion}

Fungi as an etiological agent of mastitis have also been reported by various workers [7-12]. Prevalence of Candida albicans in clinical and subclinical cases was found to be $30 \%$ and $25 \%$ (Table-2). The overall infectivity of Candida albicans was 26\%. Other researchers have also reported Candida spp as a causative agent of bovine mastitis [13-18]. This higher rate of Candida infectivity may be due to the summer.

Prevalence of Aspergillus spp in clinical and subclinical cases was found to be $40 \%$ and $37.5 \%$ (Table 2). The overall infectivity of Aspergillus spp was 38\%. Other researchers have also reported Aspergillus spp as a causative agent of bovine mastitis [19-21]. As Aspergillus spp. is a common pathogen of human skin this high incidence of may be attributed to possible transmission during milking.
A higher percentage of isolation of fungi from clinical cases and subclinical cases reveal that the incidence of fungal mastitis is increasing which may be due to unhygienic conditions of the animal sheds supporting the growth of fungal spores and hyphae in the vicinity of lactating animals. Thereby, increasing the probability of fungal spores and yeast cells to enter into the udder parenchyma which provides the best environment for the growth of these fungi $[22,23]$. It may be due to the development of antibiotic resistance in the bacteria which prolongs the course of treatment favoring chances for the fungal species such as Candida and Aspergillus to infect as secondary invader, due to the physiological changes in udder and milk. There may be the seasonal influences like high humidity along with favorable ambient temperature. Besides management practice like bathing of animals in polluted Yamuna river may be contributory. Other practices like discarding first few streaks of milk on ground while milking may be contributing factor in the increased incidences of fungal mastitis. Further detailed investigation on the mycotic and bacterial mastitis is required in relation to the hygienic and management practices as well as pattern of antibiotic therapy adopted for the treatment of these cases.

\section{Authors' contribution}

All the authors contributed equally for this study. All authors read and approved the final manuscript.

\section{Acknowledgements}

Authors are thankful to the University authorities for providing necessary facilities to carry out this research work.

\section{Competing interests}

Authors declare that they have no competing interest.

\section{References}

1. Arshad, M., Qamar, F. K., Afzal, H. and Sidique, M. (1998) Epidemiological studies of bovive mastitis in district Gujarat. Proc. Intern. Seminar on Microbial Disease of 
Livestock and Poultry, CVS, Lahore, pp: 23.

2. Krukowski, H., Lisowski, A., Ròzanski, P. and Skórka, A. (2006) Yeasts and algae isolated from cows with mastitis in the south-eastern part of Poland. Polish J Vet Sci, 9: 181-184.

3. Tarfarosh, M. A. and Purohit, S. K. (2008) Isolation of Candida spp. from Mastitic cows and Milkers. Vet. Scan, 3: 14-18.

4. Bhatia, R. and Ichhpujani, R.L. (2004) Essentials of Medical Microbiology. 3rd Edition, Jaypee Brothers Medical Publishers (P) Ltd., New Delhi.

5. Stanojevic, S. and Krnjajic D. (2002) Yeast mastitis in cows. Internet journal of Food Safety, Vol.1.pp. 8 - 10.

6. Morphology of Medically Important Fungi, 2nd Editionhttp://labmed.ucsf.edu/education/residency/fung_morph/la unchpage.html, Retrieved on 03-11-2012.

7. Costa, E. O., Ribeiro, A. R., Watanabe, E. T. and Melville, P. A. (1998) Infectious bovine mastitis caused by environmental organisms. J Vet Med B, 45(2): 65-71.

8. Gaudie, C. M., Wragg, P.N. and Barber, A. M. (2009) Outbreak of disease due to Candida krusei in a small dairy herd in the UK. Veterinary Record, 165: 535-537.

9. Türkyılmaz, S. and Kaynarca, S. (2010) The Slime Production by Yeasts Isolated from Subclinical Mastitic Cows. Acta Vet Brno,79: 581-586.doi: 10.2754/avb201079 040581.

10. Zaragoza, C. S., Olivares, R. A. C., Watty, A. E. D., Moctezuma, A. D. P. and Tanaca, L. V. (2011) Yeasts isolation from bovine mammary glands under different mastitis status in the Mexican High Plateu. Rev Iberoam Micol, 28(2):79-82.

11. Ranjan, R., Gupta, M. K. and Singh, K. K. (2011) Study of bovine mastitis in different climatic conditions in Jharkhand, India. Vet World, 4 (5), 205-208. doi:10.5455/vetworld. 2011.205-20.

12. Lagneau PE, Lebtani K and Swinne D. (1996) Isolation of yeast from bovine milk in Belgium. Mycopathologia. 1996: 135:99-102.

13. Pengov, A. (2002) Prevalence of Mycotic mastitis in cows. Acta Veterinaria (Beograd), 52: 133-136.

14. Spanamberg, A., Wünder Jr, E. A., Pereira, D. I. B., Argenta,
J., Sanches, E. M. C., Valente, P. and Ferreiro, L. (2008) Diversity of yeasts from bovine mastitis in southern Brazil. Revista Iberoamericana de Micología, 25: 154-156.

15. Santos, R. C. and Marin, J. M. (2005) Isolation of Candida spp.from mastitic bovine milk in Brazil. Mycopathologia, 159:251-253.

16. Abd El-Razik, K. A., Abdelrahman, K. A., Abd El-Moez, S. I. and Danial, . E. N., (2011) New approach in diagnosis and treatment of Bovine Mycotic Mastitis Egypt. African Journal of Microbiology Research, 5(31): 5725-5732.

17. Seker E (2010) Identification of Candida species isolated from bovine mastitic milk and their in vitro hemolytic activity in western Turkey. Mycopathologia, 169: 303-308.

18. Dworecka-Kaszak, B., Krutkiewicz, A., Szopa, D., Kleczkowski, M., and Biegańska, M. (2012) High Prevalence of Candida Yeast in Milk Samples from Cows Suffering from Mastitis in Poland, The Scientific World Journal, vol. 2012, Article ID 196347. doi:10.1100/2012/ 196347.

19. Blowey, R. and Edmondson, P. Mastitis control in dairy herds, $2^{\text {nd }}$ edition. (2010) CAB international, Cambridge, MA, 02139, USA, p- 55.

20. Mdegela, R. H., Karimuribo, E., Kusiluka, L. J. M., Kabula, B., Manjurano, A., Kapaga, A. M. and Kambarage, D. M., (2005) Mastitis in smallholder dairy and pastoral cattle herds in the urban and peri-urban areas of the Dodoma municipality in Central Tanzania. Livestock Research for Rural Development, Vol. 17, Article\#123.

21. Stephan, R., Senczek, D., Muller, C. and Feusi, C. (2000) Isolierung von Listeria spp. and Aspergillus fumigatus-zwei Fallberichte aus der Mastitisdiagnostik.Schweiz. Arch. Tierheilkd, 142:387-390.

22. Elad, D., Shpigel, N. Y., Winkler, M., Klinger, I., Fuchs, V., Saran, A. et al. (1995) Feed contamination with Candida kruse $i$ as a probable source of mycotic mastitis in dairy cows. JAVMA;207:620-2.

23. Williamson, J. H. and Di Menna, M. E. (2007) Fungi isolated from bovine udders, and their possible sources. NZ Vet J, 55:188-90. 